\section{AUTHORS:}

Charles W. Helm ${ }^{1}$

Martin G. Lockley² iD

\section{AFFILIATIONS:}

${ }^{1}$ African Centre for Coasta

Palaeoscience, Nelson Mandela

University, Port Elizabeth,

South Africa

2Dinosaur Trackers Research Group

University of Colorado Denver,

Denver, Colorado, USA

\section{CORRESPONDENCE TO:}

Charles Helm

\section{EMAIL:}

helm.c.w@gmail.com

\section{DATES:}

Received: 25 Aug. 2020

Revised: 22 0ct. 2020

Accepted: 30 0ct. 2020

Published: 29 Mar. 2021

\section{HOW TO CITE:}

Helm CW, Lockley MG. Pleistocene reptile swim traces confirmed from South Africa's Cape south coast. S Afr J Sci. 2021:117(3/4), Art. \#8830. https://doi.org/10.17159/ sajs.2021/8830

\section{ARTICLE INCLUDES:}

囚 Peer review

$\square$ Supplementary material

\section{DATA AVAILABILITY:}

$\square$ Open data set

$\square$ All data included

$凶$ On request from author(s)

$\square$ Not available

$\square$ Not applicable

EDITOR:

Margaret Avery (i)

\section{KEYWORDS:}

Pleistocene, reptiles, crocodylian swim traces, cemented foreshore deposits, trackmaker length

FUNDING:

None

\title{
Pleistocene reptile swim traces confirmed from South Africa's Cape south coast
}

\begin{abstract}
Large Pleistocene reptile tracks and traces were described from the Cape south coast of South Africa in 2020, including 'probable swim traces'. These trace fossils were found on loose slabs and blocks of the Klein Brak Formation. Subsequently, another surface has become exposed on this coastline, also on a loose slab. It exhibits more definitive evidence of swim traces in epirelief, probably made by the Nile crocodile (Crocodylus niloticus) or water monitor (Varanus niloticus), although a chelonian origin cannot be excluded. Length of a possible crocodylian trackmaker was estimated from measurements of interdigital distance in the swim traces. These provide a compelling example of reptile swim traces from Africa.

\section{Significance:}

- Pleistocene reptile swim traces have now been confidently confirmed from the Cape south coast of South Africa.

- The findings complement the suite of recently identified large reptile tracks.

- Trackmaker size can be estimated from the dimensions of reptile swim traces.

- $\quad$ These are the first compelling non-dinosaurian reptile swim traces to be described from Africa.
\end{abstract}

The coastal portion of the Garden Route National Park, on South Africa's Cape south coast, has recently yielded large reptile trace fossils. ${ }^{1}$ While evidence of tracks of the Nile crocodile (Crocodylus niloticus) and the water monitor (Varanus niloticus) was regarded as conclusive, the evidence for reptile swim traces was more equivocal. As a result, they were labelled 'probable swim traces'. ${ }^{1}$ The tracks and probable swim traces occurred on the surfaces of loose blocks and slabs which lay near the high-tide mark, having become dislodged and fallen from overlying cliffs. ${ }^{1}$

To the best of our knowledge, unequivocal reptile swim traces had not previously been reported from the continent of Africa. The only potential example was from Niger: Mudroch et al. ${ }^{2}$ reported novel theropod dinosaur tracks from a Jurassic site, and refuted the possibility of swim traces. However, Milner and Lockley ${ }^{3}$ interpreted these features as dinosaur swim traces.

The cemented rock layers containing the reptile tracks and traces on the Cape south coast occur in the Klein Brak Formation of the Bredasdorp Group. ${ }^{4}$ The Klein Brak Formation contains sediments representing a succession of shallow marine, beach, and estuarine or lagoonal deposits. ${ }^{4}$ The track-bearing surfaces were interpreted as representing a back-barrier lagoon or interdune lake. ${ }^{1}$ While optically stimulated luminescence dates were awaited for the fossil-bearing sediments, stratigraphic correlation to nearby dated deposits suggested a probable age of Marine Isotope Stage (MIS) 5e. ${ }^{1,5}$ Large reptiles do not currently inhabit the Cape south coast; it was inferred that the reptile tracks and traces had been registered during a warm interglacial period during or close to the time of a sea high-stand, which allowed large reptile species to occupy an extended range. ${ }^{1}$

Reptile swim traces may be preserved as parallel or sub-parallel grooves on epirelief surfaces, or as natural cast ridges on hyporelief surfaces. ${ }^{6-8}$ The spectrum of reptile swim traces is related to various factors, including current patterns, water depth, and trackmaker behaviour and degree of buoyancy: in very shallow sub-aqueous environments they may be virtually indistinguishable from tracks and traces made on dryland substrates, because the trackmaker can walk through shallow water without being buoyed up. In contrast, as water depth increases, causing buoyancy, typical walking tracks can be expected to become less evident, and swim traces to become more predominant. At a certain depth, only the tip of the longest digit will touch and scrape the bottom. If the water is deeper still, no trace will be registered, unless the trackmaker engaged in 'bottom-walking'. It is generally accepted that such swim tracks are often irregular. ${ }^{3}$ Such irregular contact with the substrates has been referred to as 'punting'. ${ }^{9}$ In deeper sub-aqueous settings, tail drag impressions are less common. ${ }^{10}$

We note that there are no reports in the global palaeo-ichnology record of tracks or swim traces of monitor lizards (Order: Squamata, Sub-order: Sauria, Family: Varanidae). However, fossil chelonian (Order: Chelonii) swim traces have been reported from multiple sites. ${ }^{611}$ Although the typical morphotypes of crocodylian and chelonian swim traces may readily be distinguished ${ }^{6}$, such traces are often variable in appearance, and it is not always possible to reliably make this distinction. However, some chelonians more often employ 'bottom-walking', and tracks are therefore more commonly encountered in addition to swim traces. ${ }^{6}$ Grigg and Kirshner ${ }^{12}$ noted three types of swimming in crocodylians: paraxial swimming, axial swimming and hybrid swimming, as well as bottom-walking. Axial swimming is used for rapid propulsion, and involves extensive sinuous movement of the muscular tail, while the limbs are held by the sides and are only used for steering. Swim traces of the kind recorded here are unlikely or impossible to result from such motion. Theoretically, true bottom-walking should result in a track pattern very similar to that of a trackway on dry land, and should not result in the kind of raking traces recorded here. (Proven examples of trackways registered while bottom-walking have not been documented, despite videos that show 
this mode of locomotion.) Paraxial swimming and hybrid swimming are therefore the types of motion most likely to result in raking swim traces. ${ }^{12}$

Crocodylians are a major group of archosaurs with a fossil record that extends back to the Triassic. ' Lockley et al. ${ }^{7}$ proclaimed: 'Inasmuch as dinosaurs were archosaurs of the land, and pterosaurs archosaurs of the air, extant crocodylians are archosaurs of the water'. These authors also pointed out that crocodylian swim tracks were far more common than walking traces in the fossil record. Lockley ${ }^{13}$ summarised the notion of crocodylian swim traces: 'They were inhabitants of countless prehistoric rivers, where their remains are common. Their tracks, however, are quite rare. Obviously, when in the water they did not produce many footprints. Although they would touch the bottom of river channels and ponds from time to time, tracks made when swimming are quite different from those made when walking, and often consist only of incomplete footprints and scrape marks, distributed with little sense of pattern or order. As a result, the interpretation of fossil crocodile tracks is controversial.' This conclusion has to some extent been superseded by multiple reports of unambiguous (non-controversial) crocodilian swim tracks, particularly in the Cretaceous of North America. ${ }^{6}$ In contrast, with respect to the interpretation of monitor lizard swim traces, the palaeo-ichnological record is silent.

Subsequent to the description of these 'probable swim traces'", a further site has become exposed in the same area of the Garden Route National Park, also on a loose slab which had fallen down from the cliffs above and had come to rest near the high tide mark (Figure 1). It, too, contains tracks and traces, but in this case the evidence for swim traces is much less equivocal, and is consistent with descriptions of swim traces in the global ichnological record. ${ }^{6}$ Measurements of the newly identified traces included interdigital distances, length, width, and depth. Results were recorded in centimetres. Tracings were made on clear acetate film. Photographs were taken, including photogrammetric analysis ${ }^{14}$ : three-dimensional models were generated with Agisoft MetaShape Professional (v. 1.0.4) using an Olympus TG-5 camera (focal length $4.5 \mathrm{~mm}$; resolution $4000 \times 3000$; pixel size $1.56 \times 1.56 \mathrm{um})$. The final images were rendered using CloudCompare (v.2.10-beta).

The dimensions of the trace fossil surface are $180 \mathrm{~cm} \times 70 \mathrm{~cm}$. The slab is orientated in a shore-parallel, west-east direction, just above the high tide mark, with the upper surface facing gently northwards. The lithology appears identical to that of the previously reported trackbearing surfaces 1 : the surface stratum, containing the traces, consists of a thin (less than $2 \mathrm{~cm}$ ) veneer of silt and fine sand, above and in contact with a heavily bioturbated layer. The swim traces, all of which are preserved in epirelief, are shown in Figures 2 and 3.

Recorded measurements are presented in Table 1. At the eastern end of the surface (to the left in Figures 1, 2 and 3), a probable manus-pes set of tracks is present in epirelief, with claw impressions. While these tracks are poorly preserved, as they penetrate into the underlying bioturbated layer, they bear a resemblance to the large reptile tracks described by Helm et al. ${ }^{1}$ At the western end a raised white feature, $15 \mathrm{~cm} \times 5 \mathrm{~cm}$ in size, is interpreted as a possible coprolite. Between these features a variety of swim traces is apparent. Depth varies from a maximum of 5 $\mathrm{cm}$ for the deepest track (labelled $\mathrm{A} 1$ in Table 1) to less than $1 \mathrm{~cm}$ for the smaller swim traces. The sets of swim traces, totaling at least eight (and labelled from B to I in Table 1), have an approximately unimodal orientation. They exhibit a range of digit patterns from monodactyl to pentadactyl. In some cases, they are contiguous with probable partial tracks, whereas in most cases they are consistent with 'raking traces' as described by Romano and Whyte ${ }^{8}$, without any evidence of tracks.

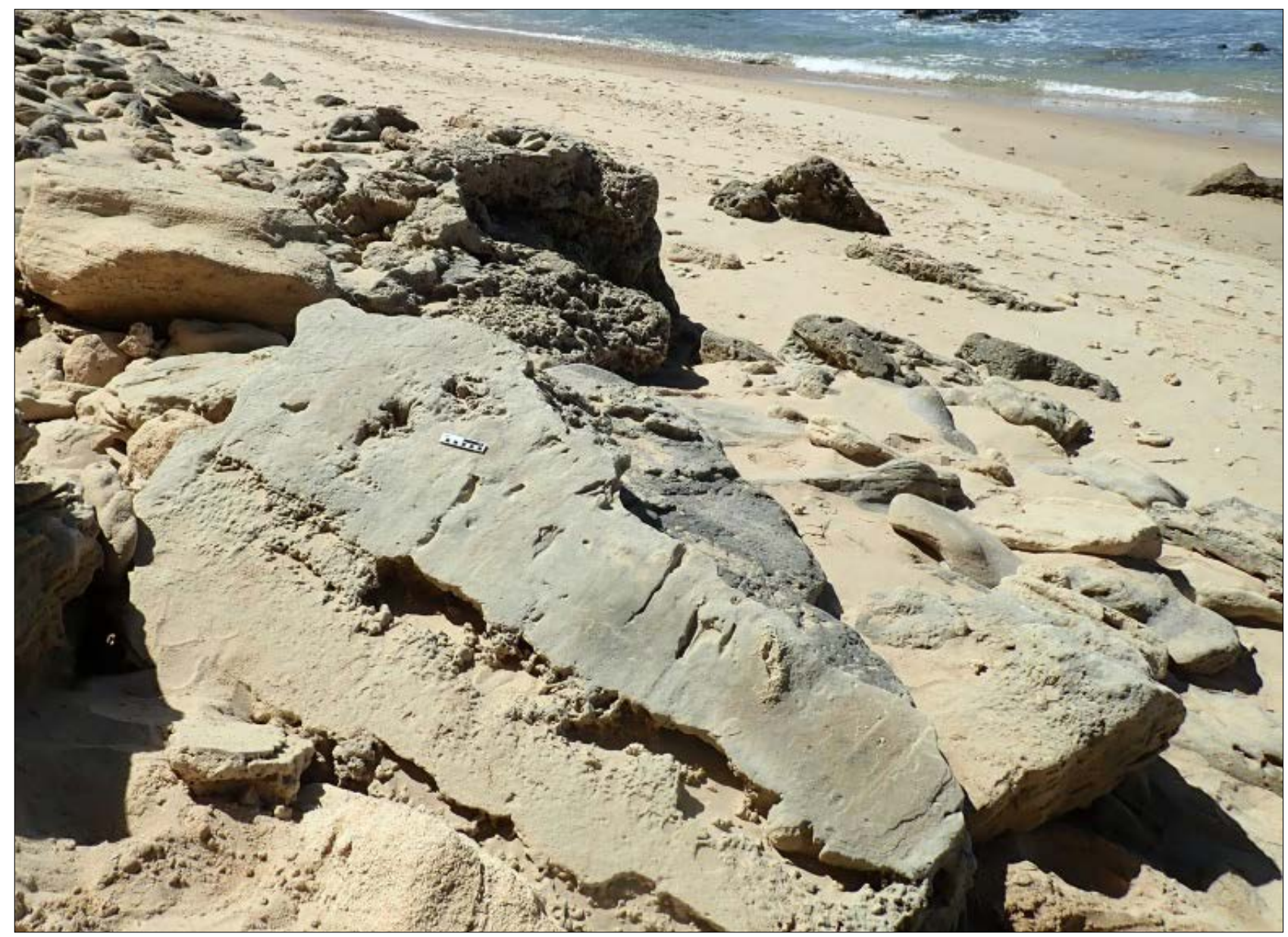

Figure 1: The loose slab containing a newly identified trace fossil-bearing surface lies near the high tide mark; scale bar $=10 \mathrm{~cm}$. 


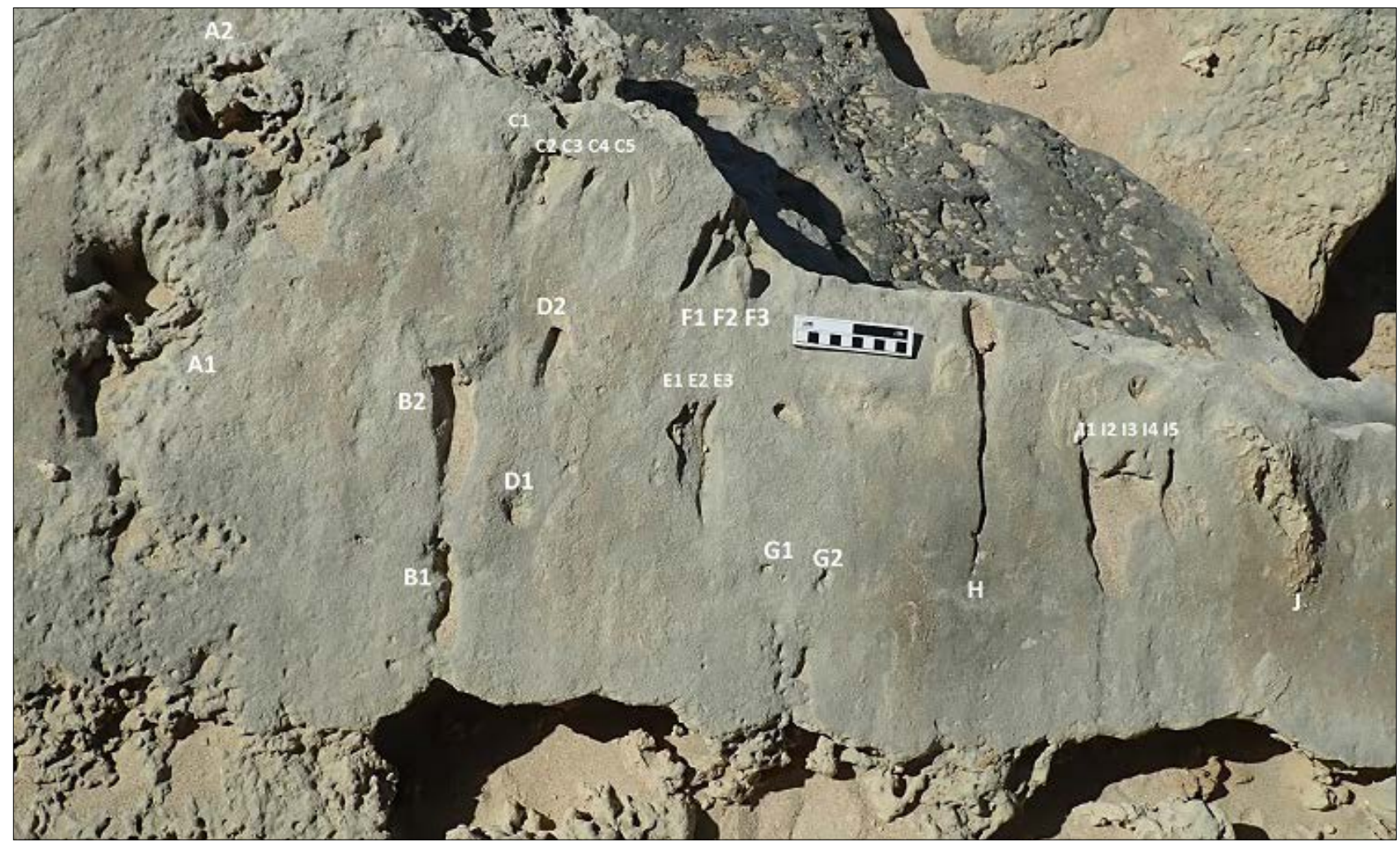

Figure 2: The trace fossil surface, facing south, with labels showing tracks, swim traces and possible coprolite; scale bar $=10 \mathrm{~cm}$. Measurements of labelled features are presented in Table 1.

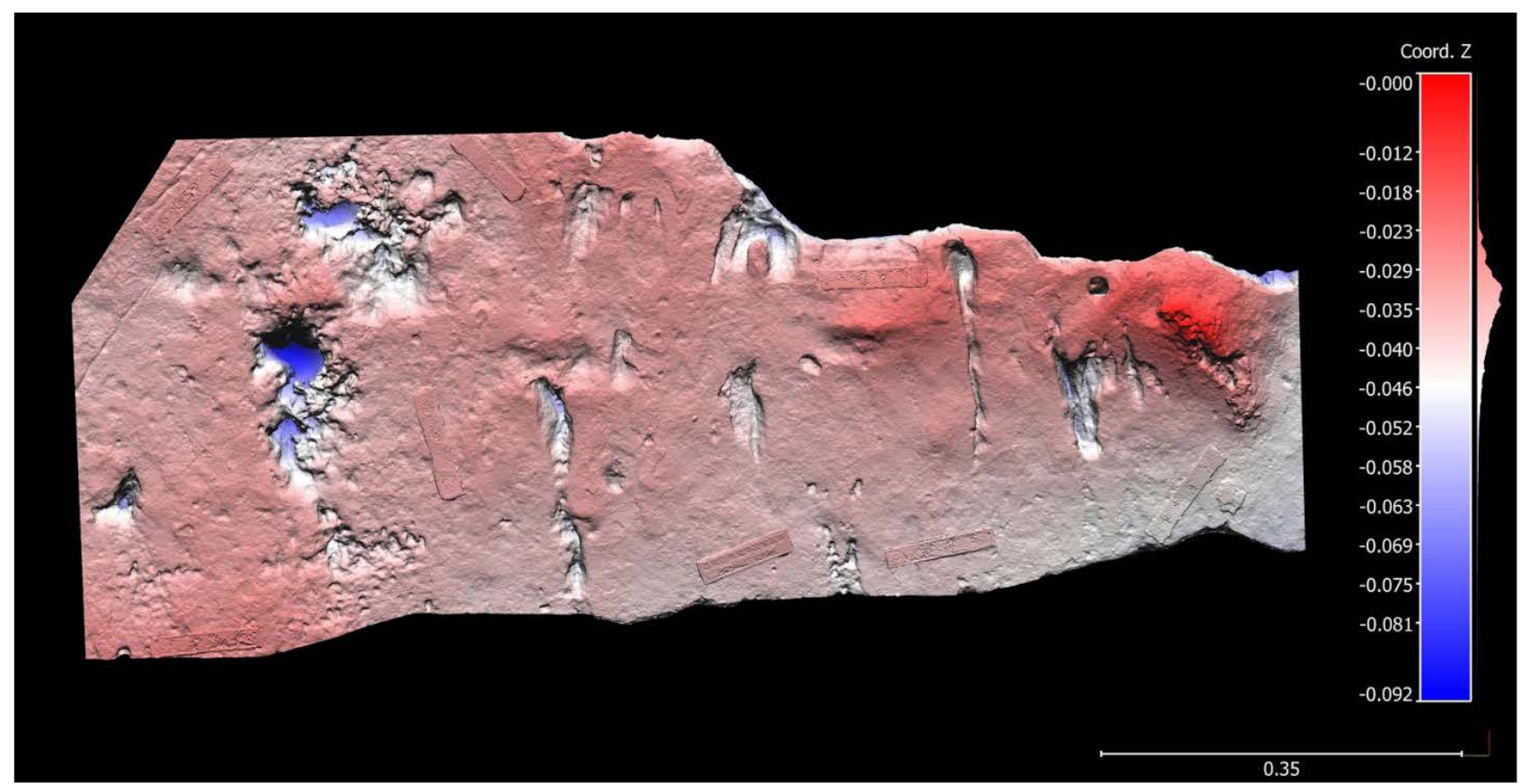

Figure 3: Photogrammetry colour mesh of tracks and swim traces, facing south. The three-dimensional model was generated with Agisoft MetaShape Professional (v. 1.0.4) using 108 images. Photos were taken an average $28.6 \mathrm{~cm}$ from the surface. The reprojection error is 0.381 pix. Vertical and horizontal scales are in metres.

Our interpretation is that the observed features may represent a deepening aqueous environment from east to west (left to right in Figures 1, 2 and 3), e.g. that the manus-pes set of tracks at the east end was thus made in shallower water, and that the traces further to the west were thus made in deeper water and were therefore registered as swim traces.
Such a deepening environment from east to west would help explain the long monodactyl trace further to the west (labelled ' $\mathrm{H}$ ' in Figure 2), which is $22 \mathrm{~cm}$ long, with a slight convexity to the west. Mean interdigital distance, where measurable (no measurement was possible for the monodactyl trace), ranges from $1.5 \mathrm{~cm}$ for the smaller sets of traces to $2.2 \mathrm{~cm}$ for the larger sets of traces. 
Table 1: Recorded measurements, in centimetres, on the surface containing tracks and traces

\begin{tabular}{|c|c|c|c|c|c|c|}
\hline Label & Length & Width & $\begin{array}{l}\text { Number of } \\
\text { traces }\end{array}$ & $\begin{array}{l}\text { Interdigital } \\
\text { distance }\end{array}$ & Convexity & Comments \\
\hline A & $\begin{array}{l}A 1=16 ? \\
A 2=7.5 ?\end{array}$ & $\begin{array}{c}\mathrm{A} 1=10 ? \\
\mathrm{~A} 2=7.5 ?\end{array}$ & $\mathrm{n} / \mathrm{a}$ & $\mathrm{n} / \mathrm{a}$ & $\mathrm{n} / \mathrm{a}$ & pes and manus tracks \\
\hline B & $\begin{array}{l}B 1=8 \\
B 2=9\end{array}$ & $\begin{array}{c}\mathrm{B} 1=1.5 \\
\mathrm{~B} 2=2\end{array}$ & $? 1$ & $\mathrm{n} / \mathrm{a}$ & to west & two traces in series \\
\hline C & $\begin{array}{c}C 1=1 \\
C 2=4.5 \\
C 3=1.5 \\
C 4=1.5 \\
C 5=1.5\end{array}$ & $\begin{array}{c}C 1=1 \\
C 2=2 \\
C 3=1 \\
C 4=1 \\
C 5=0.5\end{array}$ & 5 & $8.8 / 4=2.2$ & to west? & probably pentadactyl, with possible partial track \\
\hline D & $\begin{array}{c}\mathrm{D} 1=2 \\
\mathrm{D} 2=5.5\end{array}$ & $\begin{array}{l}\mathrm{D} 1=1.5 \\
\mathrm{D} 2=1.5\end{array}$ & 2 & $\mathrm{n} / \mathrm{a}$ & uncertain & two traces in series \\
\hline $\mathbf{E}$ & $\begin{array}{l}E 1=6 \\
E 2=7 \\
E 3=9\end{array}$ & $\begin{array}{l}\mathrm{E} 1=? \\
\mathrm{E} 2=? \\
\mathrm{E} 3=1 ?\end{array}$ & 3 & $3 / 2=1.5$ & to east & tridactyl, parallel, narrowly spaced traces \\
\hline $\mathbf{F}$ & $\begin{array}{c}F 1=7.5 \\
F 2=7.5 \\
F 3=6\end{array}$ & $\begin{array}{c}F 1=1 \\
F 2=1.5 \\
F 3=2\end{array}$ & 3 & $6.6 / 3=2.2$ & to east? & $\begin{array}{l}\text { truncated at south edge, probably tridactyl, with possible } \\
\text { track }\end{array}$ \\
\hline G & $\begin{array}{l}\mathrm{G} 1=11 \\
\mathrm{G} 2=11\end{array}$ & $\begin{array}{l}\mathrm{G} 1=<1 \\
\mathrm{G} 2=<1\end{array}$ & 2 & variable & to east & $\begin{array}{l}\text { non-parallel, intermittently registered traces, possibly } \\
\text { truncated at north edge }\end{array}$ \\
\hline H & 22 & $0.5-2$ & 1 & $\mathrm{n} / \mathrm{a}$ & to west & monodactyl \\
\hline I & $\begin{array}{l}11=14 \\
12=4.5 \\
13=4.5 \\
14=4.5 \\
15=6.5\end{array}$ & $\begin{array}{r}11=1.5 \\
12=? \\
13=? \\
14=1 \\
15=1\end{array}$ & 5 & $8 / 4=2$ & uncertain & probably pentadactyl \\
\hline J & 15 & 5 & $\mathrm{n} / \mathrm{a}$ & $\mathrm{n} / \mathrm{a}$ & $\mathrm{n} / \mathrm{a}$ & raised feature \\
\hline
\end{tabular}

In order to estimate the size of the reptiles that registered these traces, based on measured interdigital distance, data from a variety of sources was used. Thomson ${ }^{15}$ investigated the ratio of pes (hindfoot) length to total body length for $C$. niloticus. A mean ratio of $1: 12$ was obtained. ${ }^{15}$ Likewise, Milàn and Hedegaard ${ }^{10}$ concluded from studies of extant crocodylians that pes length could be used to provide a useful approximation of total length. We are not aware of similar data that can be used to estimate length of monitor lizards (varanids) or chelonians. Illustrations of $C$. niloticus tracks in three reference works ${ }^{16-18}$ on southern African tracks were compared, with attention to the ratio between pes length and interdigital distance. A mean interdigital distance to pes length ratio of 1:6.4 was obtained, and a significant difference was not apparent between interdigital distance of manus tracks and pes tracks.

In order to calculate total length from interdigital distance (if the traces were made by crocodylians), first the mean interdigital distance for a given set of swim traces was calculated, e.g. for a tetradactyl trace this involved calculating the mean of three measurements. This number was then multiplied by $77(12 \times 6.4=\sim 77)$. It is acknowledged that the resulting estimate of total length is imprecise, as it does not take into account possible splaying or adduction of digits when the swim traces were registered, as described by Sadlok and Pawełczyk ${ }^{19}$. Nonetheless, we contend that it can be used to provide an approximate indication of size. Based on the above-mentioned methods, estimated total length (if the trackmakers were crocodylians) varied from $115 \mathrm{~cm}$ for the smallest swim traces to $170 \mathrm{~cm}$ for the largest swim traces.

In conclusion, while the interpretation of tetrapod swim traces remains difficult, the newly exposed surface indicates the presence of multiple compelling examples of large reptile swim traces in Africa, thereby supplementing the evidence that led to the conclusion of 'probable swim traces' reported by Helm et al. ${ }^{1}$ Although interdigital distance recorded from swim traces may not be constant for an individual trackmaker, substantial differences in this measurement suggest that reptiles of varying size may have made the swim traces. While juvenile $C$. niloticus or juvenile $V$. niloticus may be the most likely trackmakers, a swimming chelonian trackmaker, such as a large terrapin, cannot be fully excluded on morphological grounds. Although crocodylian and chelonian swim traces are not uncommon in the global trace fossil record, swim traces of monitor lizards have not previously been reported. These appear to 
be the first compelling examples of non-dinosaurian reptile swim traces from the African continent.

\section{Acknowledgements}

We appreciate the support of Jonathan Britton, Hayley Cawthra, Xander Combrink, Jan De Vynck, Carina Helm, Renee Rust, SANParks staff, Willo Stear, Chris Stuart, Mathilde Stuart, David Thesen, Guy Thesen, and Alex van den Heever.

\section{Competing interests}

We have no competing interests to declare.

\section{Authors' contributions}

C.W.H.: Lead author, corresponding author, conceptualisation, data collection, photogrammetry, data analysis, writing, project leadership, trace fossil analysis. M.G.L.: Conceptualisation, site visit, data analysis, trace fossil analysis and contribution on ichnology, review of drafts and revisions

\section{References}

1. Helm CW, Cawthra HC, Combrink X, Helm CJZ, Rust R, Stear W, Van Den Heever A. Pleistocene large reptile tracks and probable swim traces on South Africa's Cape south coast. S Afr J Sci. 2020;116(3/4), Art. \#6542. https:// doi.org/10.17159/sajs.2020/6542

2. Mudroch A, Richter U, Joger U, Kosma R, Idé 0, Maga A. Didactyl tracks of paravian theropods (Maniraptora) from the Middle Jurassic of Africa. PLoS ONE. 2011;6(2), e14642. https://doi.org/10.1371/journal.pone.001464

3. Milner ARC, Lockley MG. Dinosaur swim track assemblages: Characteristics, contexts and ichnofacies implications. In: Falkingham PL, Marty D, Richter A, editors. Dinosaur tracks: The next steps. Bloomington, IN: Indiana University Press; 2016. p. 152-180.

4. Malan JA. Lithostratigraphy of the Klein Brak Formation (Bredasdorp Group). South African Committee for Stratigraphy Lithostratigraphic Series 13. Pretoria: Department of Mineral and Energy Affairs; 1991.

5. Bateman MD, Carr AS, Dunajko AC, Holmes PJ, Roberts DL, Mclaren SJ, et al. The evolution of coastal barrier systems: A case study of the Middle-Late Pleistocene Wilderness barriers, South Africa. Quat Sci Rev. 2011;30:63-81. https://doi.org/10.1016/j.quascirev.2010.10.003

6. Lockley MG, Cart K, Martin J, Prunty R, Houck K, Hups K, et al. A bonanza of new tetrapod tracksites from the Cretaceous Dakota Group, western Colorado: Implications for paleoecology. Bull N M Mus Nat Hist Sci. 2014;62:393-409.
7. Lockley MG, Lucas SG, Milàn J, Harris JD, Avanzini M, Foster JR, Spielmann $J A$. The fossil record of crocodylian tracks and traces: an overview. In: Milàn J, Lucas SG, Lockley MG, Spielmann JA, editors. Crocodyle tracks and traces. Bull N M Mus Nat Hist Sci. 2010;51:1-15.

8. Romano M, Whyte MA. Crocodilian and other non-dinosaurian tracks and trackways from the Ravenscar Group (Middle Jurassic) of the Cleveland Basin Yorkshire, UK. In: Milàn J, Lucas SG, Lockley MG, Spielmann JA, editors. Crocodyle tracks and traces. Bull N M Mus Nat Hist Sci. 2010;51:69-81.

9. Mustoe GE. Lower Eocene footprints from northwest Washington, USA. Part 1: Reptile tracks. Geosciences. 2019;9(321):1-19. https://doi.org/10.3390/ geosciences 9070321

10. Milàn J, Hedegaard R. Interspecific variation in tracks and trackways from extant crocodylians. In: Milàn J, Lucas SG, Lockley MG, Spielmann JA, editors. Crocodyle tracks and traces. Bull N M Mus Nat Hist Sci. 2010;51:15-29.

11. McCrea RT, Buckley LG, Currie PJ, Plint AG, Helm CW, Haggart JW. A review of vertebrate track-bearing formations from the Mesozoic and earliest Cenozoic of western Canada with a description of a new theropod ichnospecies and reassignment of an avian ichnogenus. In: Lockley MG, Lucas S, editors. Tracking dinosaurs and other tetrapods in western North America. Bull N M Mus Nat Hist Sci. 2013;62:5-94.

12. Grigg G, Kirshner D. Biology and evolution of crocodylians. Ithaca, NY: Cornell University Press / CSIRO Australia; 2015.

13. Lockley M. The eternal trail. New York: Perseus Publishing; 1999

14. Matthews NA, Noble TA, Breithaupt BH. Close-range photogrammetry for 3-D ichnology: The basics of photogrammetric ichnology. In: Falkingham PL, Marty D, Richter A, editors. Dinosaur tracks: The next steps. Bloomington, IN: Indiana University Press; 2016. p. 28-55.

15. Thomson WR. A field guide for estimating the overall length of the crocodile. S Afr J Wildl Res. 1972;2(1):27.

16. Liebenberg L. A photographic guide to tracks and tracking in Southern Africa. Cape Town; Struik Publishers; 2000.

17. Stuart C, Stuart T. A field guide to the tracks and signs of southern and East African wildlife. Cape Town: Struik Nature; 2000.

18. Van den Heever A, Mhlongo R, Benadie K. Tracker manual - a practical guide to animal tracking in southern Africa. Cape Town: Struik Nature; 2017.

19. Sadlok G, Pawełczyk K. Tetrapod swim techniques interpreted from swim trace fossils from the Lower Triassic Baranów Formation, Holy Cross Mountains, central Poland. PalZ. 2020. https://doi.org/10.1007/s12542-019-00510-w 